\title{
Animal models for the risk assessment of viral pandemic potential
}

\author{
Mee Sook Park ${ }^{\dagger}$, Jin II Kim ${ }^{\dagger}$, Joon-Yong Bae and Man-Seong Park
}

\begin{abstract}
Pandemics affect human lives severely and globally. Experience predicts that there will be a pandemic for sure although the time is unknown. When a viral epidemic breaks out, assessing its pandemic risk is an important part of the process that characterizes genomic property, viral pathogenicity, transmission in animal model, and so forth. In this review, we intend to figure out how a pandemic may occur by looking into the past influenza pandemic events. We discuss interpretations of the experimental evidences resulted from animal model studies and extend implications of viral pandemic potentials and ingredients to emerging viral epidemics. Focusing on the pandemic potential of viral infectious diseases, we suggest what should be assessed to prevent global catastrophes from influenza virus, Middle East respiratory syndrome coronavirus, dengue and Zika viruses.
\end{abstract}

Keywords: Animal model, Pandemic, Pathogenicity, Transmission, Virus, Zoonosis

\section{Introduction}

Of the four types of influenza viruses, influenza A virus (IAV) and influenza B virus (IBV) cause major respiratory diseases to humans $[1,2]$. The IAVs can be classified into different subtypes by the antigenicity of surface glycoproteins, hemagglutinin(HA) and NA(neuraminidase). So far, 18 and 11 subtypes have been identified from the HA and NA proteins, respectively, and the last two subtypes (17 and 18 subtypes in HA and 10 and 11 subtypes in NA) were recently discovered from bats [3, 4]. All other subtypes (H1 through H16 and N1 through N9) have been identified in aquatic birds, which are considered as the main reservoirs of IAVs [5]. In contrast to the IAVs, IBVs are classified into two antigenically distinct lineages, namely Victoria and Yamagata [1, 5, 6]. While the IAVs infect diverse avian and mammalian hosts including humans, the IBVs are circulating mostly among human beings with a few exceptions of spillover cases reported in seals and swine [7-10]. IAV and IBV infections

\footnotetext{
* Correspondence: ms0392@korea.ac.kr

${ }^{\dagger}$ Mee Sook Park and Jin II Kim contributed equally to this work. Department of Microbiology, Institute for Viral Diseases, College of Medicine, Korea University, Seoul, Republic of Korea 02841
}

show similar clinical signs of 'influenza-like illness' and outcomes [11-14].

There have been four major influenza pandemics since 1918 with some glimpses of pandemic-like events in history [15-17]. The H1N1 influenza pandemic of 1918 (pdm1918) is estimated to have caused up to 50 million human deaths across the globe [18], symbolizing how devastating one pandemic outbreak can be. It is believed that influenza pandemics can be occurred by antigenic shift, which generally results from the introduction of certain gene segment(s) from nonhuman sources to human infecting IAVs through a genetic reassortment process $[5,16]$. The efficient human-to-human transmission and lack of immunity against the novel virus in humans can be driving forces to facilitate the dissemination of the virus and then to result in a pandemic. After a pandemic wave, the virus may lose momentum under increasing immune pressures among humans and persist as a seasonal virus. This seasonal virus will retain genetic mutations by circulating season by season, and its viral antigenicity may change, which is so-called antigenic drift, and it is the main reason that the vaccine viruses need updates every year. Currently, the H1N1 and 
H3N2 subtypes of IAVs, which are the descendants of 2009 and 1968 influenza pandemics, respectively, and the Victoria and Yamagata lineages of IBVs are circulating as seasonal viruses in humans.

Before the H1N1 pandemic in 2009 (pdm2009), an avian H5N1 IAV had been remarked as a strong candidate that would cause a next pandemic given accumulating human infection cases with the virus $[19,20]$. Recently, an avian H7N9 virus has become the focus of attention concerning the increasing number of human infection cases in China [21, 22]. However, it is important to remember that pdm2009 was caused unexpectedly by a swine origin IAV [16], emphasizing the importance of the surveillance of swine IAVs [23]. There are also other subtypes of avian HA and NA isolated from human influenza cases sporadically [24, 25]. Given their pandemic potential, we need to assess these humaninfecting zoonotic IAVs in detail by comparing with the viruses that had caused past influenza pandemics.

Recently, Middle East respiratory syndrome coronavirus (MERS-CoV) is dubbed 'camel-flu' virus [26]. Seven years after its first human infection in 2012 [27-29], more than 2400 human cases have been reported with approximately $35 \%$ case fatality rate [30]. MERS-CoV has a singlestranded positive-sense RNA genome consisting of two partially overlapping large replicase open reading frames (ORFs) and at least nine downstream ORFs including the ORFs encoding the four canonical structural proteins of coronaviruses, the envelope proteins $\mathrm{S}, \mathrm{E}$, and $\mathrm{M}$ and the $\mathrm{N}$ protein [31]. Similarity of MERS-CoV with influenza viruses is not in its genome organization but probably in its respiratory symptoms, zoonotic potential, and the mode of respiratory transmission [32-34]. In addition to influenza viruses and MERS-CoVs, arthropod-borne viruses, such as dengue and Zika, may also pose pandemic threats even though persistent human-to-human transmissions have been rarely reported [35-39]. In this review, we intend to figure out the recipe and the ingredients of a pandemic by looking into the past pandemic events.

\section{Main text}

\section{Zoonotic origins of influenza pandemics}

IAVs have eight segmented genomes of single-stranded, negative-sense RNAs, which express similar major proteins, such as polymerase basic 2 (PB2), polymerase basic 1 (PB1), polymerase acidic (PA), HA, nucleoprotein (NP), NA, matrix 1 (M1) and matrix 2 (M2), nonstructural 1 (NS1), and nonstructural 2 (NS2/NEP) [1]. Studying the past influenza pandemics helps us to understand the mechanisms of such devastating outcomes. Theoretically,144 different IAV subtype viruses can be generated by the combinations of $16 \mathrm{HA}$ and 9 NA subtypes of avian IAVs. However, only the H1N1, $\mathrm{H} 2 \mathrm{~N} 2$, and H3N2 subtypes have been identified as the causes of human influenza pandemics. Of these, the H1N1 subtype caused the 1918 and 2009 pandemics and the 'abortive pandemic'-like swine influenza epidemic in 1976, which hundreds of soldiers at Fort Dix, New Jersey, the United States were infected with [15, 40, 41] (Fig. 1). Although diverse IAV subtypes have been isolated from swine, $\mathrm{H} 1, \mathrm{H} 2$ and $\mathrm{H} 3$, and N1 and N2 subtypes have been mainly established [42-44]. As mentioned above, the pdm2009 and $1976 \mathrm{H} 1 \mathrm{~N} 1$ viruses were swine-origin and readily transmissible among humans $[15,16,45]$. Another pandemic H1N1 virus, pdm1918, however, appeared to be closely related with avian strains, which would be ultimately the ancestor of subsequent human and swine H1N1 IAVs [46]. Since human-infecting avian IAVs were shown to be less transmissible among humans [47-49], a 'spill-over' infection with avian IAVs was not likely to be a

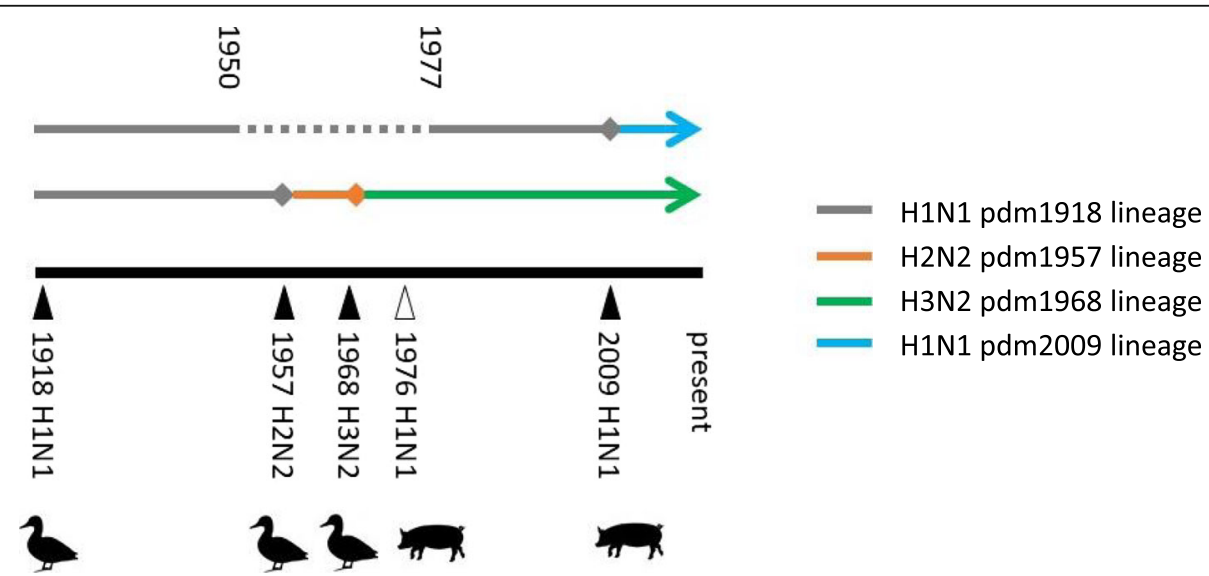

Fig. 1 Timeline of influenza pandemics. Each pandemic event is marked by a bold arrowhead on the timeline, which is not to the scale. The open arrowhead designates the 'aborted pandemic'. The animal symbols designate the host origins of the HAs of the pandemic strains. Lines with the diamond heads designate the duration and the end of the circulation. The arrowed lines designate being circulated currently. The dotted lines designate unknown 
direct source of pdm1918 [50, 51]. As the receptor specificity is considered another prerequisite for avian IAVs to infect and transmit to humans, there are some doubts about the avian-origin pdm1918 [52]. The H2 HA of the 1957 H2N2 pandemic and the H3 HA of the $1968 \mathrm{H} 3 \mathrm{~N} 2$ pandemic were introduced from the avian reservoir to circulating human IAVs [53, 54], but whether the reassortment events occurred in humans or in other hosts, such as swine, immediately before transmitting to humans remains unanswered [16].

\section{Swine as an adaptation host of IAVs}

IAVs can be largely divided into the human-like and avianlike types given the receptor specificity of their HA proteins. Normally, human-like IAVs bind to $\alpha-2,6$ sialic acid $(\alpha-2,6 \mathrm{SA})$ receptor whereas avian-like IAVs prefer $\alpha-2,3$ SA receptor $[55,56]$. It has been revealed that an aquatic bird mallard expresses more $\alpha-2,3$ SA than $\alpha-2,6$ SA in the respiratory tract but $\alpha-2,6 \mathrm{SA}$ is barely expressed in the intestinal tracts [57]. The preference of avian IAVs to $\alpha-2,3$ SA might be related with fecal transmission of the viruses $[58,59]$. Regarding zoonotic transmission of IAVs, swine is considered the intermediate host that can shuffle genetic segments between avian and human IAVs to produce a novel strain [54]. Because swine expresses both $\alpha-2,3$ and $\alpha-2,6$ SAs in the upper respiratory tract, avian and human IAVs all can infect swine [60-62]. It has been also challenged by additional studies that demonstrated similar SA distribution between human and swine [63-66]. However, it has been shown that avian IAVs could transmit between swine, and novel strains could be generated from contact swine by the genetic reassortment between avian and swine IAVs [67], which cannot be demonstrated in humans. Hence, it appears that swine rather than humans may play a major role for the generation of novel strains at the interface of avian and human IAVs [68-70], and swine might be considered an adaptation host of IAVs, as indicated in the cases of zoonosis [71-76] and reverse zoonosis of IAVs [43, 77]. Then, it should be questioned whether avian IAVs can be transformed into a pandemic virus by the adaptation only in humans. Even though some reports indicated acquired transmissibility of avian IAVs through multiple passages in ferrets [78] and transmissibility of avian IAVs in swine [67], it may be limited contact opportunities of the same avian IAV to be repeatedly adapted in humans, as demonstrated in Herfst et al. [78]. Whether a rare adaptive mutant would grow out to dominate in the human host would be another issue. Unlike severe symptoms observed in novel avian IAV-infected patients, however, swine may be asymptomatic when infected with avian IAVs $[79,80]$. Unless efficient transmissibility of an avian IAV in humans was adaptively acquired during a single human infection, there would be only very limited close contact transmission from the patient to the care giver. Close contact transmission of avian H7N9 IAVs between patients and care givers have been recognized, but the contacted care givers have rarely shown the signs of infection [8183]. This may demonstrate why avian IAVs have acquired necessary adaptive mutations in swine rather than in humans to be pandemic viruses [69].

\section{Ingredients and recipe of influenza pandemics}

From the examples of the past influenza pandemics discussed so far, the recipe of a pandemic may be drawn up. The ingredients of influenza pandemics appear to be (1) non-human animal reservoir(s) that provides novel antigenic sources continuously, (2) adaptation host(s) where accumulated mutations result in host specificity changes or genetic reassortment occurs, (3) proper transmissibility between adaptation host(s) and humans back and forth, (4) efficient human-to-human transmission, and (5) pathogenicity in humans (Fig. 2). The second and third ingredients may work together to generate a virus with the human adapted genes with a new antigenic flavor. We have seen that the influenza pandemics came about with these ingredients and the human activity of socializing and traveling. Determining whether a virus has these ingredients might be an important step in assessing its pandemic potential.

\section{Influenza epidemics}

The sudden reappearance of 1950s seasonal H1N1 strains in 1977 that was dubbed 'Russian flu' right after the 1976 swine IAV epidemic spurred the awareness of the need for pandemic planning [15, 40]. Although the virus had rapidly spread among people under 25 years of age and had been 'drifting' as seasonal strains until the appearance of the pdm2009 [18], the $1977 \mathrm{H} 1 \mathrm{~N} 1$ virus may not be considered a pandemic virus. The virus was only a reappearance of previous human IAV most likely by an accidental release and met an immunity gap among young people. The virus was not of a nonhuman reservoir origin, according to the pandemic ingredients summarized above. In case of the H5N1 and H7N9 avian IAVs, they may lack efficient transmissibility to and between humans. However, as shown in ferret studies, they should be under close surveillance for their pandemic potential in advance. In addition to these avian IAVs, swine IAVs should be also monitored because novel strains can be generated by genetic reassortment in swine between avian and human IAVs, as presented in the genesis of pdm2009. In contrast to IAVs, IBVs do not have animal reservoirs, so they might be considered a virus of less pandemic potential.

\section{MERS-CoV}

MERS-CoV appeared to originate from a bat coronavirus [28, 84-87] and has become enzootic since a certain 


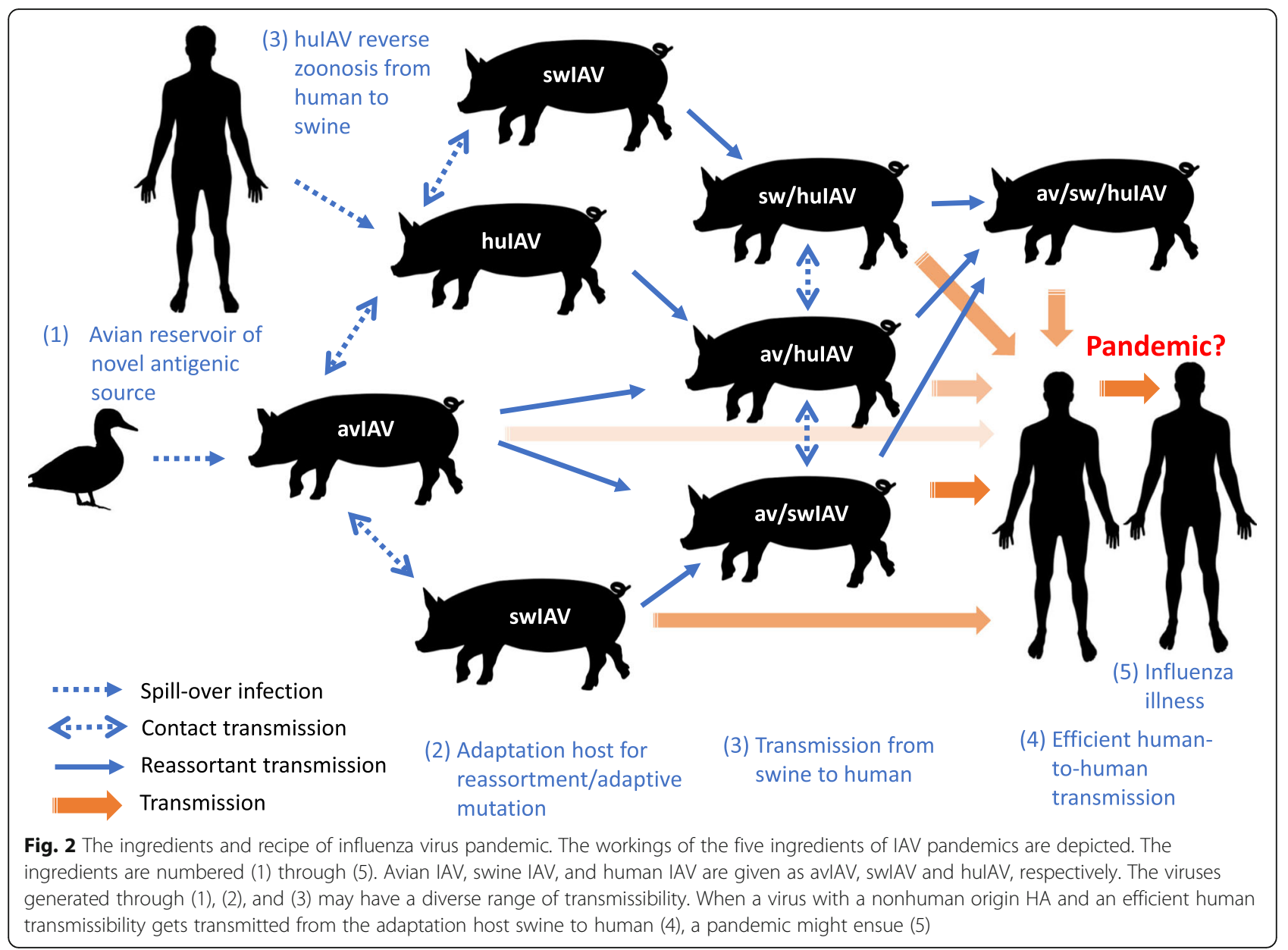

time point among dromedary camels [32, 88-90], which is readily transmissible to and between humans [34]. Unlike other human virus, such as measles [91], MERS$\mathrm{CoV}$ might evolve constantly in the dromedary camels [92], which show a high rate of seroconversion and carry the virus mostly asymptomatically [90]. Continuous back and forth transmission between humans and the dromedary camels constitutes very similar situations with IAVs. Frequent recombination during MERS-CoV replication in the reservoir host [93-95] might be used as a tool of adaptation by antigenically novel MERS-CoV strains or closely related bat coronaviruses, similarly as genetic reassortments of IAVs in swine [96]. If there might be a MERS-CoV pandemic, subsequent MERSCoV epidemics by antigenically 'drifted' strains might follow the pattern of seasonal influenza viruses until antigenically shifted (recombined) MERS-CoV strains hit humans again.

\section{Dengue and Zika viruses}

Mosquitos are a vector and non-human reservoir of dengue and Zika viruses. Back and forth transmission of these viruses between mosquitos and humans and the 'antibody dependent enhancement' of infection to dengue and Zika viruses might potentially support the expansion of susceptible human pools [97-99]. However, currently there are very limited cases of human-tohuman transmission of these viruses through body fluid contacts [35-39], and it is unlikely to result in rapid global spreading of the viruses like IAVs, especially since mosquito distribution is geographically limited [100]. Hence, possible human-to-human transmission of the dengue and Zika viruses is inevitably limited by the requirement of intimate contacts or blood transfusion [101]. Even though this ecological limitedness, solid control measures against mosquitos should be implemented to prevent dissemination of these arthropod-borne viral diseases in a global scale.

\section{Animal models}

Small laboratory animals are surrogate models used in the experiments of human infecting viruses. Viral behaviors in a natural host are often different from those in humans. Viruses causing serious diseases in humans are often asymptomatic in their natural hosts. This is why natural hosts have a limitation as animal models. In case 
of IAVs, avian and swine species should be considered the natural reservoir animals, and in case of MERSCoVs, bats and dromedary camels [32, 87, 90]. Viruses causing severe diseases and deaths in humans are the targets of prevention and control. Researches using animal models for such viruses are carried out in two main directions: (1) investigation of viral characteristics in hosts, such as replication capacity, cellular tropisms, pathogenicity, and transmission, and (2) development of antivirals and vaccines. No animal models can be a perfect replicate of humans. Certain animal models can have advantages in representing viral infection and, at the same time, disadvantages in other aspects. Therefore, experimental questions may determine the best animal model, and experiments should be conducted such a way that the results obtained using animal models can be translated to humans.

\section{Animal models of influenza viruses}

Non-reservoir animals used for influenza virus infection experiments include ferrets, mice, guinea pigs, Syrian hamsters, and non-human primates [102-109]. Historically, the discovery of the first human influenza virus was made by infecting ferrets with throat washings of influenza patients [110]. Ferrets could also be readily infected with swine influenza virus. The different species of guinea pigs, mice, rabbits, hamsters, hedgehogs, and monkeys did not develop flu-like symptoms [103]. However, these asymptomatic animals have become useful for special purposes of influenza virus infection experiments now because virus detection and titration methods have become sophisticated (Table 1). Especially, mice and guinea pigs are the most accessible animal models cost- and space-wise. In the case of mice, human infecting influenza viruses do not usually infect mice well, which is overcome by adapting the virus in mice through serial passages $[103,119,120]$. Mice express the avian type $\alpha-2,3 \mathrm{SA}$ in the lower respiratory tract, similarly as humans, but not the human type $\alpha$ 2,6 SA [121]. This is in line with the tendency of experimentally inoculated avian IAVs, regardless of lowpathogenic (LPAIV) or highly pathogenic avian IAVs (HPAIV), being mouse lethal with a relatively low $50 \%$ mouse lethal dose $\left(\mathrm{MLD}_{50}\right)[104,122]$. As far as seasonal isolates of human IAVs are concerned, DBA/2 mice have been shown to be highly susceptible to diverse strains of un-adapted IAVs [123, 124]. Ferrets, guinea pigs, and Syrian hamsters could be infected with most of IAVs without adaptation, but only guinea pigs could be infected with IBV without adaptation and supported the airborne transmission $[108,111]$. Syrian hamster has been tried to replace mice because IAVs could infect it without adaptation and there were airborne transmissions among Syrian hamsters [108]. However, since guinea pigs can be infected with un-adapted IBVs as well as IAVs and support airborne transmissions, which is readily detectable by the nasal wash titer, any advantage of Syrian hamsters over guinea pigs awaits further reports of the use of animal models in influenza virus research. Nonhuman primates (NHPs) are genetically closest to humans. Although NHPs are not a readily accessible animal model, NHPs are indispensable in the cases of vaccine and antiviral tests, where data relevant to humans in terms of pharmacokinetics and physiology are critical [125]. 'Animal Efficacy Rule' of the United States Food and Drug Administration (FDA) requires for the therapeutics to demonstrate efficacy in two animal models manifesting human-like symptoms including at least one non-rodent model [126]. Although the needs of testing in NHP models are clearly present [113-117], most laboratories cannot afford NHPs, and there is other ethical uneasiness about using NHPs. How best to do without NHPs may be a persisting issue in search of appropriate animal models. In the case of influenza virus research, among the frequently used animal models, ferrets appear to be the only non-rodent model other than NHPs [127].

\section{Animal models of MERS-CoV infection}

Animal models of MERS-CoV are restricted by the availability of the receptor DPP4 that contains distinct amino acid sequence motif. Besides the reservoir host dromedary camels and bats, NHPs, rabbits, and other livestock animals, such as goat, cow, sheep, and pig, have been shown to express DPP4 that can bind to MERS-CoV [85, 128-130]. However, DPP4 of frequently used small

Table 1 Animal models for influenza virus

\begin{tabular}{lllll}
\hline Animal model & Model for & & & References \\
\cline { 2 - 4 } & Pathogenicity & Transmission & Antiviral & \\
\hline Ferret & O & 0 & 0 & {$[103,104]$} \\
Mouse & 0 & $?$ & $?$ & {$[103,104]$} \\
Guinea pig & $?$ & 0 & $?$ & {$[103,104,111,112]$} \\
Syrian hamster & $?$ & $?$ & $?$ & {$[104,108]$} \\
Nonhuman primate & 0 & $?$ & & {$[104,113-118]$} \\
\hline
\end{tabular}

The designation of " $\mathrm{O}$ " means that there are many studies using the animal for the purposed study

The designation of "?" means that there are no or not many studies using the animal for the purposed study 
animal models like mouse, hamster, and ferret did not bind to MERS-CoV [128]. In NHPs, MERS-CoV infection showed similar clinical signs as in humans, ranging from mild to severe, depending on the species of NHPs. Although DPP4 expressions were similar between rhesus macaques and common marmosets, the disease severity was from mild to moderate and from moderate to severe, respectively [131, 132]. Lack of replication of MERS-CoV in small animal models poses problems of cost and space, especially since experiments using MERS-CoV must be carried out in an animal biosafety level 3 facility [29, 133-135]. Mouse engineering technology has been deployed in diverse ways to generate mice expressing human type DPP4 (hDPP4) [136-140]. MERS-CoV infection in mice having hDPP4 exhibited only moderate signs of respiratory pathology, most likely due to the low level expression of hDPP4 in the mouse lung [135], but MERS-CoV could be adapted in these mice to a more pathogenic virus $[139,141]$. In addition to NHP and hDPP4-mouse models, rabbits might be a good candidate for MERS-CoV transmission experiments due to its camel-like receptor distribution in the upper respiratory tract (Table 2) [142, 150]. However, while dromedary camels and New World camelids could transmit MERS-CoV upon contact, rabbits could hardly transmit the virus $[130,143]$. MERS-CoV has been shown to use $\alpha-2,3$ SA as a receptor assistant, which dromedary camels but not rabbits express in the nasal epithelium $[130,151,152]$. Humans do not express the primary receptor DPP4 in the upper respiratory tract but transmits MERS-CoV well [153]. Despite the controversies, humans have been reported to express $\alpha-2,3 \mathrm{SA}$ in the upper respiratory tract $[61,64]$. Contribution of the 'pre-attachment' receptor $\alpha-2,3 \mathrm{SA}$ or any other 'assistant' receptors to MERS-CoV transmission might be worth further investigation [151]. As far as the Animal Efficacy Rule of FDA is concerned, there appears no other choices but hDPP4-mouse and NHP models in the case of MERS-CoV studies. Human-like symptoms of MERS-CoV infection have not been reproduced in other animals than hDPP4-mice and NHPs.

\section{Host determinants contributing to pandemic viruses}

Starting from the distinct receptor specificities of the HA proteins between avian and human IAVs, host restriction determinants of IAVs have been documented [56]. Receptor specificity and amino acid signatures at PB2 residue 627 are well established host determinants critical for the interhost transmission of IAVs [154]. However, IAVs with avian or human receptor specificity can infect swine, as mentioned above. Furthermore, the PB2 protein of the triple reassortant swine IAV lineage, which comprises a majority of North American swine IAVs [155], retains the avian type E627 (glutamate in the PB2 residue 627) [156]. This was also a part of the molecular signatures of pdm2009 [16]. Some human infecting avian IAV isolates have shown acquisition of the human type K627 (lysine in the PB2 residue 627) but not acquisition of the human type receptor specificity determinants, and some acquisition of both [80, 157, 158]. IAVs were shown to bind cells lacking sialic acid, and replicated efficiently [159]. Acquisition of PB2 K627 might be more advantageous than acquisition of human type receptor specificity for avian IAVs to replicate in the upper respiratory tract of humans, which is not an optimal temperature for PB2 E627 [157]. It has been also shown that the PB2 E627K mutation can emerge in a human case infected with an avian IAV [160]. Of note is that, although there have been avian-to-human transmission cases of avian H5N1 and H7N9 IAVs, there have been no sustained human-to-human transmission of avian IAVs. Indeed, it has been reported that an H5N1 HPAIV harboring the human-type PB2 E672K mutation (change from glutamate to lysine in the position 627) and human-type HA Q226L and G228S mutations (change from glutamine to leucine and from glycine to serine in positions 226 and 228, respectively, by $\mathrm{H} 3$ numbering) by itself could not transmit via airborne droplets between ferrets [78]. This may suggest that airborne transmissibility of avian IAVs in humans might not be determined only by the presence or absence of molecular determinants. Several studies using reassortant viruses have shown that the competence of reassortant viruses may not be predicted simply by the presence of the specific molecular determinants [161164]. An experiment testing a swine 'mixing vessel' hypothesis by co-housing pigs infected with an avian H1N1 strain or with a swine H3N2 strain and naive pigs revealed 40 and $60 \%$ transmission efficiency, respectively [67]. In that experiment, the reassortant viruses

Table 2 Animal models for MERS-CoV

\begin{tabular}{lllll}
\hline Animal model & Model for & & & References \\
\cline { 2 - 5 } & Pathogenicity & Transmission & Antiviral & \\
\hline hDPP4-mouse & O & $?$ & 0 & {$[136-140]$} \\
Rabbit & $?$ & $?$ & $?$ & {$[142-145]$} \\
Nonhuman primate & 0 & $?$ & 0 & {$[131,132,134,146-149]$} \\
\hline
\end{tabular}

The designations of "O" and "?" are the same as in Table 1 
appeared to be well replicated (59/63) in the middle or lower respiratory tract, regardless of the presence of swine $\mathrm{PB} 2$ or avian $\mathrm{PB} 2$, although all but one reassortants $(62 / 63)$ contained the swine HA. Four out of the 63 reassortants did replicate in the upper respiratory tract and three out of four of those were the swine PB2containing reassortants [67]. What we can learn from this experiment is that the reassortant with an avian HA is not frequently selected in pigs and that the reassortant with swine PB2 is selected for the replication in the upper respiratory tract of pigs. The proportion of IAV infection in farmed pigs is relatively low [68], and the likelihood of co-existing of pigs infected with avian IAVs and/or with swine IAVs in the same pen may be even lower. However, avian and swine IAV reassortants have been established and isolated in pigs [155], which is the evidence of ongoing 'genetic mixing' of IAVs.

\section{From surveillance to determination of the pandemic potential of viruses}

Surveillance of newly emerging IAVs may be approached in two ways; isolating and sequencing a virus using nextgeneration sequencing (NGS). As we discussed above, it is not enough to look for the molecular determinants by sequencing. Even though full genome sequences are recovered, and their evolutionary relationships are reconstructed, further studies using the viruses should be carried out [165, 166]. The classical method of growing viruses in MadinDarby canine kidney (MDCK) and human airway epithelial A549 cells might be the first step after a genetic sequence analysis. The MDCK cells express both $\alpha-2,3$ and $\alpha-2,6$ SAs and support replication of influenza viruses ubiquitously due to the lack of the Mx protein anti-influenza signaling [167, 168]. Therefore, viral growth in the MDCK cells is considered to evaluate the inherent growth potential of the viruses under such a condition where no innate and adaptive immune responses of the host are counted in [157]. On the other hand, the A549 cells, expressing more $\alpha-2,6$ SA than $\alpha-2,3$ SA like in the human upper respiratory tract, may indicate the growth potential of the viruses in the human upper respiratory tract $[169,170]$. Any swine isolates - avian, swine endemic, or reassortant origin - showing equivalent to or better growth rates in MDCK and A549 cells than the swine-origin pdm2009 virus may be further studied for their pathogenicity and transmissibility in animal models, to determine their pandemic potential.

\section{Viral pathogenicity and transmission in animal models as pandemic potential}

Viral pathogenicity is related to host cell tropism but may be separate from the susceptibility of hosts to the virus. IAVs are pathogenic to humans but not guinea pigs, although both are permissive to the virus. The degree of pathogenicity, the virulence of an IAV, is inevitably associated with how well the virus replicates in a tissue or an organ, impairment of which results in a serious disease. In cases of respiratory viruses, those replicating in the lower respiratory tract tend to be more pathogenic than those in the upper respiratory tract $[171,172]$. Therefore, viral pathogenicity is closely related to inherent replication ability and receptor specificity of the virus. An avian IAV with PB2 K627 has been shown to replicate better in both upper and lower respiratory tracts in mice and more pathogenic to the infected mice than with PB2 E627 [157]. However, in case of the pdm2009 isolate A/California/04/09 virus (CA04), the virus lacked previously identified molecular markers of IAV virulence or transmissibility [173], although was more pathogenic to mice than the seasonal H1N1 virus [174-176]. Droplet transmissibility of pdm2009 in ferrets was shown to be slightly lower than the seasonal H1N1 virus whereas their contact transmissibilities were equally efficient [174]. This suggests that antigenic novelty might play a more important role for the pandemic potential of a certain IAV than viral transmissibility.

\section{Mice as a pathogenicity indicator of IAVs}

Ferrets have been known to have human-like glycan distributions in their respiratory tract and may develop respiratory symptom after IAV infection [104, 127]. However, although most human IAVs including swine IAVs are not pathogenic to mice, mice could be a good initial testing model in terms of cost and handling easiness compared with ferrets, especially for an isolate containing avian origin HAs. Since mice have $\alpha-2,3$ SA in the lower respiratory tract [121], avian IAVs tend to be pathogenic to mice without a prior adaptation [177]. Therefore, viral pathogenicity in mice could be an initial pathogenicity indicator of certain IAVs. The first pdm2009 isolate CA04 was more pathogenic in BALB/c mice than the later pdm2009 isolates [176]. The pdm2009 isolates from fatal cases were also more pathogenic in mice than from the mild cases, and replacing the HA of the mild case isolate with that from the fatal case could make a more pathogenic virus in mice [178]. These experiments show that IAV pathogenicity in mice may reflect inherent lung pathogenicity of IAVs in humans. However, the results of mouse experiments should be interpreted in comparison with a pathologically well-characterized control.

\section{Human IAVs adapted in mice vs. avian IAVs adapted for human-to-human transmission}

Through a serial adaptation process, more pathogenic viral isolates can be recovered. For an IAV with the receptor specificity to $\alpha-2,6$ SA to replicate in mice, where there is hardly any or small amount of $\alpha-2,6 \mathrm{SA}$ in the respiratory tract $[121,179,180]$, the virus must have used surrogate receptors 
such as C-type lectins or else [181-183]. IAVs have been shown to bind to and replicate in SA-free or sialidase treated cells, although to a lower degree than in the untreated cells $[159,183]$. Abolishing NA activity has been shown to be another mechanism of adapting to the host expressing a low level of the specific receptor [184]. Indeed, the HA protein of a mouse-adapted pdm2009 has been shown to have acquired higher affinity to $\alpha-2,3 \mathrm{SA}$ and lower affinity to $\alpha-2,6 \mathrm{SA}$ compared to the wild type [185]. The difference between a human IAV adapted in mouse and an avian IAV infecting humans may be determined by the usage and availability of appropriate SA or equivalent molecules. To be pathogenic to mice, human IAVs with $\alpha-2,6 \mathrm{SA}$ specificity must adapt to use non-SA receptors or $\alpha-2,3$ SA abundant in mice [180], but avian IAVs with $\alpha-2,3$ SA specificity may have a possibility to replicate in the lower respiratory tract of humans without a prior adaptation.

\section{Conceptual design of human, swine, and ferret respiratory tracts}

It has been known that humans express $\alpha-2,3$ and $\alpha-2,6$ SAs in the lower and upper respiratory tracts, respectively [61]. But, it has been also reported that humans express both $\alpha-2$, 3 and $\alpha-2,6$ SAs at a similar level in the upper respiratory tract [64]. Given the availability of animal models that reflect human respiratory diseases, we conceptually suggest human, swine, and ferret respiratory tracts in Fig. 3, based on the study of de Graaf et al. [63]. Human or swine IAVs with $\alpha-2$, $6 \mathrm{SA}$ specificity would be trapped in the upper respiratory tract of the respective host, where $\alpha-2,6 \mathrm{SA}$ is abundant (Fig. $3 a)$. Some replicating viruses may overflow down to the lower respiratory tract, where both $\alpha-2,3$ and $\alpha-2,6$ SAs are expressed. Avian IAVs with $\alpha-2,3$ SA specificity would be also trapped in the upper respiratory tract by $\alpha-2,3 \mathrm{SA}$, but replicate poorly due to the unfavorable temperature. Under such circumstances, only a high dose of avian IAVs allows to escape the trapping in the upper respiratory tract and reach the lower respiratory tract, where the temperature is more favorable for avian IAVs. Even though avian IAVs might overflow from the lower respiratory tract up to the upper respiratory tract, the virus might not replicate there due to the unfavorable temperature, unless there was the PB2 E627K mutation. This may be the reason that avian IAVs are not easily transmissible between humans. In terms of viral adaptation, a rare appearance of avian IAV mutants with $\alpha$ 2,6 SA specificity may not have special selective growth advantages in the lower respiratory tract of humans due to the overwhelming dominance of $\alpha-2,3$ SA. Only when avian IAVs replicating in the upper respiratory tract, although poorly, acquires the PB2 E627K mutation or a reassortment, with or without acquisition of $\alpha-2,6$ SA specificity at the same time, the variants may grow out well [67]. Serial passaging of a wild-type H5N1 HPAIV in ferrets could not make the virus airborne transmissible between ferrets, but only those containing the mutations conferring the human type $\alpha-2,6$ SA specificity and PB2 E627K could acquire airborne transmissibility after several passages in ferrets [78]. Basically, these experiments suggest that, even if a rare mutant retaining the human-type receptor specificity and PB2 determinants might appear during replication of avian IAVs, the mutant might not be easily selected to a domination over multiple passages, at least in ferrets. The reason may be that avian IAVs have their niche of efficient replication in the lower respiratory tract of human, swine, or ferret (Fig. 3). The issue of avian IAV adaptation in humans may not be whether adaptive mutations appears but whether there is a selective force enough for a virus to possess adaptive mutations to grow out to dominance.

\section{Experimental observation and conceptual transmission model}

The HA protein of avian H5N1 IAVs has been reported to require both human-type Q226L and G228S mutations to bind to both $\alpha-2,3$ and $\alpha-2,6$ SAs [186], and that of avian H7N9 IAVs only needs the Q226L mutation [122, 187]. Interestingly, a H7N9 human isolate was contact transmissible in pigs, regardless of PB2 E627 or K627, but only in the acquisition of human-type HA Q226L determinant, which indicates the importance of the acquisition of human-type receptor specificity for the avian IAV transmission in pigs, potentially also in humans [188]. However, as demonstrated in Fig. 3b and c, the acquisition of human-type PB2 K627 would have been more critical due to the presence of SA $\alpha-2,3$ glycans in the upper respiratory tract of pigs. Avian IAVs with the PB2 E627K mutation should be able to replicate in the upper respiratory tract of humans and may be transformed to be transmissible between humans (Fig. 3c). However, they were poorly transmissible in ferrets (Fig. 3d). There have been no reports that investigated the transmissiblity of avian IAVs with the PB2 E627K mutation between humans. All the first three human isolates of avian H7N9 IAVs, which contained the human-type PB2 E627K and HA Q226L mutations, showed approximately $30 \%$ airborne transmissibility in ferrets $[48,80,122]$. These appear to match with the conceptualized transmission in ferrets of Fig. 3d. The H7N9 isolates with PB2 K627 and HA L226 would have replicated in the upper respiratory tract of ferrets, but their replication might have been inefficient since the receptor binding of the H7N9 Q226L HA was still weaker to $\alpha-2,6$ SA than to $\alpha-2,3$ SA [187]. Airborne transmission of the H7N9 virus in ferrets lacking $\alpha-2,6 \mathrm{SA}$ might be explained by the overflow of the virus replicating in the lower respiratory tract, since ferrets poorly express $\alpha-2,3 \mathrm{SA}$ in the upper respiratory tract [189]. This model also indicates similar level of transmission of avian IAVs in ferrets without any human-type determinants. 


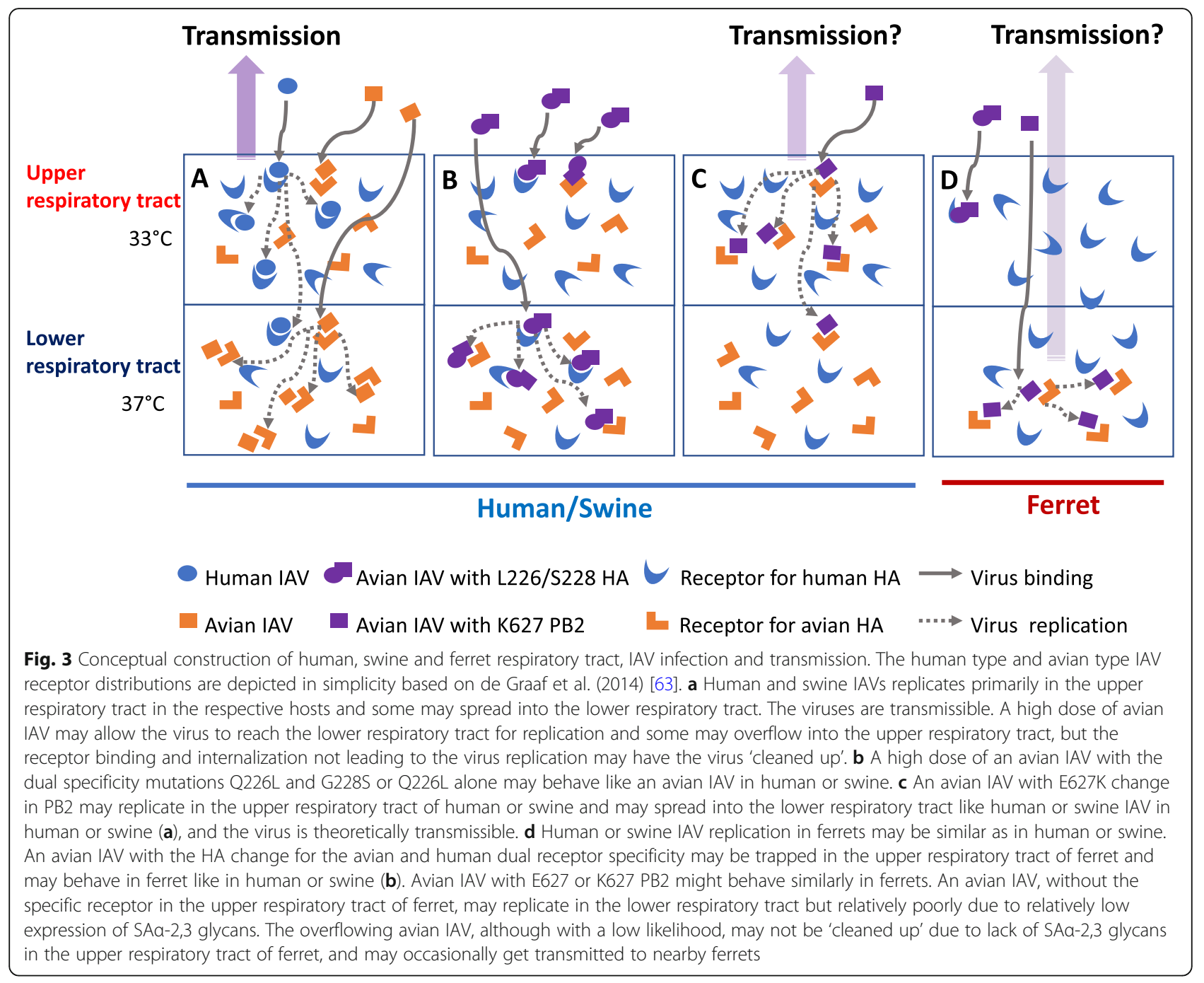

Therefore, the conceptual model of IAV transmission based on the receptor distribution appears to agree only with the ferret experiments, and probably only with H7N9 transmission in ferrets, since avian H5N1 IAVs were not transmissible in ferrets $[78,190]$. This conceptual model is apparently an oversimplification. There may be more factors involved in the transmission of IAVs, such as the functional balance between the HA and NA proteins and inherent replicability of IAVs [191, 192]. The problem is, due to the discrepancy between what is expected in humans by the conceptual model and the reality, how to translate the results of transmission experiments evaluated in animal models to the natural transmission environments between humans. We may compare the transmissibility of certain viral isolates to that of CA04 in ferrets, but it is difficult to determine what the level of the transmissibility of these viruses indicate in terms of the pandemic potential of the viruses. The reports on the $\alpha-2,3$ SA expression status in the upper respiratory tract of ferrets, pigs, and humans appear to be inconclusive [63]. Determination of IAV receptor distributions in humans and animal models appears critical for the interpretation of pathogenicity and transmission experiments assessed in animal models.

\section{Pandemic potential of MERS-CoV}

We have discussed how to approach to the determination of the pandemic potential of IAVs. Similar principles may apply to MERS-CoVs. Previously, MERS-CoV replication was noted in NHP-derived cell lines, Vero, and LLC-MK2 cells [28]. It is now known that DPP4 is a functional cellular receptor for MERS-CoVs and that Vero cells express DPP4 [193]. Vero cells also express $\alpha$ 2,3 SA, which has been shown to assist receptor binding of MERS-CoVs [130, 151, 152, 167]. Vero cells are well known for an impairment in the type I interferon pathways [194]. Hence, Vero cells for MERS-CoV infection may function like MDCK cells for influenza viruses. Growth of MERS-CoVs in Vero cells may indicate their inherent replication potential. Better growths of MERS- 
CoVs in the upper respiratory tract is likely to contribute to their better transmission [143]. Therefore, growth characteristics of camel MERS-CoVs in Vero cells may give us initial clues about how efficient the transmission of novel strains might be.

\section{Pathogenicity of MERS-CoVs in hDPP4 mice}

The pathogenicity of MERS-CoVs is closely associated with DPP4 expression in the lower respiratory tract of humans [153]. Like IAVs, the pathogenicity of MERS$\mathrm{CoV}$ in hDPP4 mice may be an initial indicator. While hDPP4 mice produced severe symptoms upon MERS$\mathrm{CoV}$ infection [140], mice whose mDPP4 replaced with hDPP4 or modified to contain MERS-CoV binding hDPP4 motif (m-hDPP4-mice) showed little clinical signs $[138,139]$. hDPP4 mice might be good for the evaluation of antiviral candidates, but not as a pathogenicity indicator, due to the ectopic expression of hDPP4. hDPP4 mice might be better to observe increases of growths and clinical signs after MERS-CoV infection. Comparison of viral titers in the lungs and the lung pathology of MERS-CoV infection with those of the first MERS-CoV isolate $\mathrm{HCoV}$-EMC [28] would give clues concerning the replication potential of MERS-CoVs.

\section{Surrogate models for the evaluation of MERS-CoV transmission}

There are no small animal models for the evaluation of MERS-CoV transmission yet. Even though avian IAVs transmit extremely poorly between humans, MERSCoVs appears highly transmissible between humans. In case of MERS-CoV outbreaks in Korea, 2015, a superspreader individual resulted in 28 infection cases [34]. However, it is difficult to appropriately interpret the transmissibility difference between IAVs and MERS$\mathrm{CoVs}$ in ferrets. Due to the distribution differences of DPP4 and $\alpha-2,3$ SA in the lower and upper respiratory tracts in humans and dromedary camels, it might be a major problem in translating the results of transmission experiments using small animal models. HCoV-EMC exhibited no transmission in rabbits [143], and a kind of transmission threshold has not been defined, so it would be a problem to determine the pandemic potential of MERS-CoV isolates. The DPP4 motif of NHPs have the same sequence with that of humans [132, 147]. However, no MERS-CoV transmission has been reported between NHPs. Hence, some kinds of surrogate measures might be necessary to evaluate the transmissibility of MERS-CoVs. Mice are not capable of contact or aerosol transmitting IAV but can be infected with aerosolized live-attenuated influenza vaccine virus using a nebulizer [195]. Since it has been reported that the lower respiratory tract of hDPP4 mice is very similar to that of humans, replication kinetics of a MERS-CoV isolate in the lungs of hDPP4 mice would provide a clue concerning transmissibility and virulence of MERS-CoVs. This suggests the feasibility and importance of hDPP4 mice for the evaluation of replication or transmissibility of MERS-CoVs.

\section{Conclusion}

We have discussed what may be required to be a pandemic virus by analyzing the past influenza pandemics. The uniqueness of the past influenza pandemics is in that the three pools of reservoirs or hosts (avian, swine, and human) keep the persistent potential of generating novel IAVs and that no other pathogens are known to bring about pandemics recurrently. Moreover, the ingredients of the influenza pandemics and the modes of transmission may apply to other pathogens exhibiting pandemic potential. Unlike IAVs, MERS-CoVs have not swept global communities and appeared to need a persistent human reservoir. The ultimate goal of MERS$\mathrm{CoV}$ researches may find a way to prevent a MERS-CoV pandemic. Studying the pandemic viruses, such as pdm1918 and pdm2009, may provide scientific information regarding molecular and viral requirements of potential pandemic viruses. Our conceptual interpretation of animal models also underlines the value and importance of preclinical experiments in terms of the translational purposes and insights of the pandemic potential of influenza and other RNA viruses.

\section{Acknowledgements}

We would like to thank Sang Woo Kim, Juho Do, Dahae Hong, and Eunji Choi for technical assistance with the animal experiments.

Authors' contributions

M-SP outlined this review. MSP, JIK, J-YB, and M-SP wrote this review. The authors read and approved the final manuscript.

\begin{abstract}
Funding
This study was supported by a grant from the National Research Foundation of Korea (NRF) funded by the Ministry of Science and ICT, Republic of Korea (grant no. NRF-2017R1A2B2003773). The funders had no role in study design, data collection and interpretation, or the decision to submit the work for publication.
\end{abstract}

Availability of data and materials Not applicable.

\section{Competing interests}

The authors declare no competing interests.

Received: 28 January 2020 Accepted: 10 March 2020

Published online: 22 April 2020

\section{References}

1. P. Palese MS. Orthomyxoviridae. In: PMH DMK, editor. Fields virology, vol. 1. 6th ed. Philadelphia: Wolters Kluwer Health/Lippincott Williams \& Wilkins; 2013

2. Sreenivasan CC, Thomas M, Kaushik RS, Wang D, Li F. Influenza A in bovine species: a narrative literature review. Viruses. 2019;11(6):10.3390/v11060561.

3. Ciminski K, Thamamongood T, Zimmer G, Schwemmle M. Novel insights into bat influenza A viruses. J Gen Virol. 2017;98(10):2393-400. 
4. Wu Y, Wu Y, Tefsen B, Shi Y, Gao GF. Bat-derived influenza-like viruses H17N10 and H18N11. Trends Microbiol. 2014;22(4):183-91.

5. GN PFW, Kawaoka Y. Orthomyxoviruses. In: PMH DMK, editor. Fields virology, vol. 1. 6th ed. Philadelphia: Wolters Kluwer Health/Lippincott Williams \& Wilkins; 2013.

6. Rota PA, Wallis TR, Harmon MW, Rota JS, Kendal AP, Nerome K. Cocirculation of two distinct evolutionary lineages of influenza type $B$ virus since 1983. Virology. 1990;175(1):59-68.

7. Bodewes R, Morick D, de Mutsert G, Osinga N, Bestebroer T, van der Vliet S, et al. Recurring influenza B virus infections in seals. Emerg Infect Dis. 2013; 19(3):511-2.

8. Osterhaus AD, Rimmelzwaan GF, Martina BE, Bestebroer TM, Fouchier RA. Influenza B virus in seals. Science. 2000;288(5468):1051-3.

9. Ran Z, Shen H, Lang Y, Kolb EA, Turan N, Zhu L, et al. Domestic pigs are susceptible to infection with influenza B viruses. J Virol. 2015;89(9):4818-26.

10. Takatsy G, Farkas E, Romvary J. Susceptibility of the domestic pig to influenza B virus. Nature. 1969;222(5189):184-5.

11. Irving SA, Patel DC, Kieke BA, Donahue JG, Vandermause MF, Shay DK, et al. Comparison of clinical features and outcomes of medically attended influenza A and influenza B in a defined population over four seasons: 2004-2005 through 2007-2008. Influenza Other Respi Viruses. 2012;6(1):37-43.

12. Wang Y, Fan G, Horby P, Hayden F, Li Q, Wu Q, Zou X, Li H, Zhan Q, Wang C, et al. Comparative outcomes of adults hospitalized with seasonal influenza A or B virus infection: application of the 7-category ordinal scale. Open Forum Infect Dis. 2019;6(3):ofz053.

13. Su S, Chaves SS, Perez A, D'Mello T, Kirley PD, Yousey-Hindes K, et al. Comparing clinical characteristics between hospitalized adults with laboratory-confirmed influenza A and B virus infection. Clin Infect Dis. 2014; 59(2):252-5.

14. Tran D, Vaudry W, Moore D, Bettinger JA, Halperin SA, Scheifele DW, et al. Hospitalization for influenza A versus B. Pediatrics. 2016;138(3):e20154643.

15. Kilbourne ED. Influenza pandemics of the 20th century. Emerg Infect Dis. 2006:12(1):9-14.

16. Neumann G, Kawaoka Y. The first influenza pandemic of the new millennium Influenza Other Respi Viruses. 2011:5(3):157-66.

17. Morens DM, Taubenberger JK. Historical thoughts on influenza viral ecosystems, or behold a pale horse, dead dogs, failing fowl, and sick swine. Influenza Other Respi Viruses. 2010;4(6):327-37.

18. Neumann G, Noda T, Kawaoka Y. Emergence and pandemic potential of swine-origin H1N1 influenza virus. Nature. 2009;459(7249):931-9.

19. Ligon BL. Avian influenza virus $\mathrm{H} 5 \mathrm{~N} 1$ : a review of its history and information regarding its potential to cause the next pandemic. Semin Pediatr Infect Dis. 2005;16(4):326-35.

20. Fauci AS. Pandemic influenza threat and preparedness. Emerg Infect Dis. 2006;12(1):73-7.

21. de Vries RD, Herfst S, Richard M. Avian influenza A virus pandemic preparedness and vaccine development. Vaccines (Basel). 2018;6(3):10.3390/ vaccines 6030046

22. Sutton $\mathrm{TC}$. The pandemic threat of emerging $\mathrm{H} 5$ and $\mathrm{H} 7$ avian influenza viruses. Viruses. 2018;10(9):10.3390/v10090461.

23. Kim JI, Lee I, Park S, Lee S, Hwang MW, Bae JY, et al. Phylogenetic analysis of a swine influenza $A(\mathrm{H} 3 \mathrm{~N} 2)$ virus isolated in Korea in 2012. PLoS One. 2014;9(2):e88782.

24. Alexander DJ, Brown IH. Recent zoonoses caused by influenza A viruses. Rev Sci Tech. 2000;19(1):197-225.

25. Mostafa A, Abdelwhab EM, Mettenleiter TC, Pleschka S. Zoonotic potentia of influenza A viruses: a comprehensive overview. Viruses. 2018;10(9):10. 3390/v10090497.

26. Yong $\mathrm{CY}$, Ong HK, Yeap SK, Ho KL, Tan WS. Recent advances in the vaccine development against Middle East respiratory syndrome-coronavirus. Front Microbiol. 2019;10:1781.

27. Bermingham A, Chand MA, Brown CS, Aarons E, Tong C, Langrish C, et al. Severe respiratory illness caused by a novel coronavirus, in a patient transferred to the United Kingdom from the Middle East, September 2012 Euro Surveill. 2012:17(40):20290

28. Zaki AM, van Boheemen S, Bestebroer TM, Osterhaus AD, Fouchier RA. Isolation of a novel coronavirus from a man with pneumonia in Saudi Arabia. N Engl J Med. 2012;367(19):1814-20.

29. Raj VS, Osterhaus AD, Fouchier RA, Haagmans BL. MERS: emergence of a novel human coronavirus. Curr Opin Virol. 2014;5:58-62.
30. Middle East respiratory syndrome coronavirus (MERS-CoV). https://www. who.int/emergencies/mers-cov/en/. Accessed 12 Dec 2019.

31. van Boheemen S, de Graaf M, Lauber C, Bestebroer TM, Raj VS, Zaki AM, et al. Genomic characterization of a newly discovered coronavirus associated with acute respiratory distress syndrome in humans. MBio. 2012; 3(6):10.1128/mBio.00473-12.

32. Peck KM, Burch CL, Heise MT, Baric RS. Coronavirus host range expansion and Middle East respiratory syndrome coronavirus emergence: biochemical mechanisms and evolutionary perspectives. Annu Rev Virol. 2015;2(1):95-117.

33. Choi S, Jung E, Choi BY, Hur YJ, Ki M. High reproduction number of Middle East respiratory syndrome coronavirus in nosocomial outbreaks: mathematical modelling in Saudi Arabia and South Korea. J Hosp Infect. 2018;99(2):162-8

34. Lee JY, Kim YJ, Chung EH, Kim DW, Jeong I, Kim Y, et al. The clinical and virological features of the first imported case causing MERS-CoV outbreak in South Korea, 2015. BMC Infect Dis. 2017;17(1):498.

35. Kyle JL, Harris E. Global spread and persistence of dengue. Annu Rev Microbiol. 2008;62:71-92.

36. Lalle E, Colavita F, lannetta M, Gebremeskel Tekle S, Carletti F, Scorzolini L, et al. Prolonged detection of dengue virus RNA in the semen of a man returning from Thailand to Italy, January 2018. Euro Surveill. 2018;23(18):10. 2807/1560-7917.ES.2018.23.18.18-00197.

37. Wilder-Smith A, Chen LH, Massad E, Wilson ME. Threat of dengue to blood safety in dengue-endemic countries. Emerg Infect Dis. 2009;15(1):8-11.

38. Joguet G, Mansuy JM, Matusali G, Hamdi S, Walschaerts M, Pavili L, et al. Effect of acute Zika virus infection on sperm and virus clearance in body fluids: a prospective observational study. Lancet Infect Dis. 2017;17(11): $1200-8$.

39. Casale TB, Teng MN, Morano JP, Unnasch T, Lockwood CJ. Zika virus: an emerging infectious disease with serious perinatal and neurologic complications. J Allergy Clin Immunol. 2018;141(2):482-90.

40. Iskander J, Strikas RA, Gensheimer KF, Cox NJ, Redd SC. Pandemic influenza planning, United States, 1978-2008. Emerg Infect Dis. 2013;19(6):879-85.

41. Gaydos JC, Top FH Jr, Hodder RA, Russell PK. Swine influenza A outbreak, fort dix, New Jersey, 1976. Emerg Infect Dis. 2006;12(1):23-8.

42. Brockwell-Staats $C$, Webster RG, Webby RJ. Diversity of influenza viruses in swine and the emergence of a novel human pandemic influenza $A(H 1 N 1)$. Influenza Other Respi Viruses. 2009;3(5):207-13.

43. Zhu H, Webby R, Lam TT, Smith DK, Peiris JS, Guan Y. History of swine influenza viruses in Asia. Curr Top Microbiol Immunol. 2013;370:57-68.

44. Zell R, Scholtissek C, Ludwig S. Genetics, evolution, and the zoonotic capacity of European swine influenza viruses. Curr Top Microbiol Immunol. 2013;370:29-55.

45. Pulit-Penaloza JA, Belser JA, Tumpey TM, Maines TR. Sowing the seeds of a pandemic? Mammalian pathogenicity and transmissibility of $\mathrm{H} 1$ variant influenza viruses from the swine reservoir. Trop Med Infect Dis. 2019;4(1):10. 3390/tropicalmed4010041.

46. Taubenberger JK. The origin and virulence of the 1918 "Spanish" influenza virus. Proc Am Philos Soc. 2006;150(1):86-112

47. Tumpey TM, Maines TR, Van Hoeven N, Glaser L, Solorzano A, Pappas C, et al. A two-amino acid change in the hemagglutinin of the 1918 influenza virus abolishes transmission. Science. 2007;315(5812):655-9.

48. Zhu H, Wang D, Kelvin DJ, Li L, Zheng Z, Yoon SW, et al. Infectivity, transmission, and pathology of human-isolated H7N9 influenza virus in ferrets and pigs. Science. 2013;341(6142):183-6.

49. Zaraket H, Bridges OA, Duan S, Baranovich T, Yoon SW, Reed ML, et al. Increased acid stability of the hemagglutinin protein enhances H5N1 influenza virus growth in the upper respiratory tract but is insufficient for transmission in ferrets. J Virol. 2013;87(17):9911-22.

50. Fanning TG, Slemons RD, Reid AH, Janczewski TA, Dean J, Taubenberger JK. 1917 avian influenza virus sequences suggest that the 1918 pandemic virus did not acquire its hemagglutinin directly from birds. J Virol. 2002;76(15):7860-2.

51. Glaser L, Stevens J, Zamarin D, Wilson IA, Garcia-Sastre A, Tumpey TM, et al. A single amino acid substitution in 1918 influenza virus hemagglutinin changes receptor binding specificity. J Virol. 2005;79(17):11533-6.

52. Worobey M, Han GZ, Rambaut A. Genesis and pathogenesis of the 1918 pandemic H1N1 influenza A virus. Proc Natl Acad Sci U S A. 2014;111(22): $8107-12$.

53. Parrish CR, Kawaoka Y. The origins of new pandemic viruses: the acquisition of new host ranges by canine parvovirus and influenza A viruses. Annu Rev Microbiol. 2005;59:553-86. 
54. Webster RG, Bean WJ, Gorman OT, Chambers TM, Kawaoka Y. Evolution and ecology of influenza A viruses. Microbiol Rev. 1992;56(1):152-79.

55. Rogers GN, Paulson JC. Receptor determinants of human and animal influenza virus isolates: differences in receptor specificity of the $\mathrm{H} 3$ hemagglutinin based on species of origin. Virology. 1983;127(2):361-73.

56. Long JS, Mistry B, Haslam SM, Barclay WS. Host and viral determinants of influenza A virus species specificity. Nat Rev Microbiol. 2019;17(2):67-81.

57. Costa T, Chaves AJ, Valle R, Darji A, van Riel D, Kuiken T, et al. Distribution patterns of influenza virus receptors and viral attachment patterns in the respiratory and intestinal tracts of seven avian species. Vet Res. 2012;43:28.

58. VanDalen KK, Franklin AB, Mooers NL, Sullivan HJ, Shriner SA. Shedding light on avian influenza H4N6 infection in mallards: modes of transmission and implications for surveillance. PLoS One. 2010;5(9):e12851.

59. Kang HM, Choi JG, Kim MC, Kim HR, Oem JK, Bae YC, et al. Isolation of a reassortant H13N2 virus from a mallard fecal sample in South Korea. Virol J. 2012;9:133.

60. Ito T, Couceiro JN, Kelm S, Baum LG, Krauss S, Castrucci MR, et al. Molecular basis for the generation in pigs of influenza $A$ viruses with pandemic potential. J Virol. 1998;72(9):7367-73.

61. Shinya K, Ebina M, Yamada S, Ono M, Kasai N, Kawaoka Y. Avian flu: influenza virus receptors in the human airway. Nature. 2006;440(7083):435-6.

62. Kumlin U, Olofsson S, Dimock K, Arnberg N. Sialic acid tissue distribution and influenza virus tropism. Influenza Other Respi Viruses. 2008;2(5):147-54.

63. de Graaf M, Fouchier RA. Role of receptor binding specificity in influenza A virus transmission and pathogenesis. EMBO J. 2014;33(8):823-41.

64. Nicholls JM, Bourne AJ, Chen H, Guan Y, Peiris JS. Sialic acid receptor detection in the human respiratory tract: evidence for widespread distribution of potential binding sites for human and avian influenza viruses. Respir Res. 2007:8:73.

65. Nelli RK, Kuchipudi SV, White GA, Perez BB, Dunham SP, Chang KC. Comparative distribution of human and avian type sialic acid influenza receptors in the pig. BMC Vet Res. 2010;6:4.

66. Trebbien R, Larsen LE, Viuff BM. Distribution of sialic acid receptors and influenza A virus of avian and swine origin in experimentally infected pigs. Virol J. 2011:8:434

67. Zhang X, Sun H, Cunningham FL, Li L, Hanson-Dorr K, Hopken MW, et al. Tissue tropisms opt for transmissible reassortants during avian and swine influenza A virus co-infection in swine. PLoS Pathog. 2018;14(12):e1007417.

68. Bowman AS, Nolting JM, Workman JD, Cooper M, Fisher AE, Marsh B, et al. The inability to screen exhibition swine for influenza A virus using body temperature. Zoonoses Public Health. 2016;63(1):34-9.

69. Weingartl HM, Albrecht RA, Lager KM, Babiuk S, Marszal P, Neufeld J, et al. Experimental infection of pigs with the human 1918 pandemic influenza virus. J Virol. 2009;83(9):4287-96.

70. Kaplan BS, Torchetti MK, Lager KM, Webby RJ, Vincent AL. Absence of clinical disease and contact transmission of HPAI H5NX clade 2.3.4.4 from North America in experimentally infected pigs. Influenza Other Respi Viruses. 2017;11(5):464-70.

71. Dowdle WR, Hattwick MA. Swine influenza virus infections in humans. J Infect Dis. 1977;136(Suppl):S386-9.

72. Pulit-Penaloza JA, Belser JA, Tumpey TM, Maines TR. Mammalian pathogenicity and transmissibility of a reassortant Eurasian avian-like A(H1N1v) influenza virus associated with human infection in China (2015). Virology. 2019:537:31-5.

73. Shinde V, Bridges CB, Uyeki TM, Shu B, Balish A, Xu X, et al. Triplereassortant swine influenza $A(H 1)$ in humans in the United States, 20052009. N Engl J Med. 2009;360(25):2616-25.

74. Terebuh P, Olsen CW, Wright J, Klimov A, Karasin A, Todd K, et al. Transmission of influenza A viruses between pigs and people, lowa, 20022004. Influenza Other Respi Viruses. 2010;4(6):387-96.

75. Bowman AS, Walia RR, Nolting JM, Vincent AL, Killian ML, Zentkovich MM, et al. Influenza $A(H 3 N 2)$ virus in swine at agricultural fairs and transmission to humans, Michigan and Ohio, USA, 2016. Emerg Infect Dis. 2017;23(9): 1551-5.

76. Schicker RS, Rossow J, Eckel S, Fisher N, Bidol S, Tatham L, et al. Outbreak of influenza $\mathrm{A}(\mathrm{H} 3 \mathrm{~N} 2)$ variant virus infections among persons attending agricultural fairs housing infected swine - Michigan and Ohio, July-august 2016. MMWR Morb Mortal Wkly Rep. 2016;65(42):1157-60.

77. Nelson MI, Stratton J, Killian ML, Janas-Martindale A, Vincent AL. Continual reintroduction of human pandemic H1N1 influenza $A$ viruses into swine in the United States, 2009 to 2014. J Virol. 2015;89(12):6218-26.
78. Herfst S, Schrauwen EJ, Linster M, Chutinimitkul S, de Wit E, Munster VJ, et al. Airborne transmission of influenza A/H5N1 virus between ferrets. Science. 2012;336(6088):1534-41.

79. Lipatov AS, Kwon YK, Sarmento LV, Lager KM, Spackman E, Suarez DL, et al. Domestic pigs have low susceptibility to H5N1 highly pathogenic avian influenza viruses. PLoS Pathog. 2008;4(7):e1000102.

80. Gao R, Cao B, Hu Y, Feng Z, Wang D, Hu W, et al. Human infection with a novel avian-origin influenza A (H7N9) virus. N Engl J Med. 2013;368(20):1888-97.

81. Qi X, Qian YH, Bao CJ, Guo XL, Cui LB, Tang FY, et al. Probable person to person transmission of novel avian influenza A (H7N9) virus in eastern China, 2013: epidemiological investigation. BMJ. 2013;347:f4752.

82. Hu J, Zhu Y, Zhao B, Li J, Liu L, Gu K, et al. Limited human-to-human transmission of avian influenza $\mathrm{A}(\mathrm{H} 7 \mathrm{~N} 9)$ virus, Shanghai, China, march to April 2013. Euro Surveill. 2014;19(25):10.2807/1560-7917.es2014.19.25.20838.

83. Zhou L, Chen E, Bao C, Xiang N, Wu J, Wu S, et al. Clusters of human infection and human-to-human transmission of avian influenza $A(H 7 N 9)$ virus, 2013-2017. Emerg Infect Dis. 2018;24(2):397-400.

84. Widagdo W, Begeman L, Schipper D, Run PRV, Cunningham AA, Kley N, et al. Tissue distribution of the MERS-coronavirus receptor in bats. Sci Rep. 2017;7(1):1193.

85. Munster VJ, Adney DR, van Doremalen N, Brown VR, Miazgowicz KL, MilnePrice $S$, et al. Replication and shedding of MERS-CoV in Jamaican fruit bats (Artibeus jamaicensis). Sci Rep. 2016;6:21878.

86. Cai Y, Yu SQ, Postnikova EN, Mazur S, Bernbaum JG, Burk R, et al. CD26/ DPP4 cell-surface expression in bat cells correlates with bat cell susceptibility to Middle East respiratory syndrome coronavirus (MERS-CoV) infection and evolution of persistent infection. PLoS One. 2014;9(11): e112060.

87. Cui J, Eden JS, Holmes EC, Wang LF. Adaptive evolution of bat dipeptidyl peptidase 4 (dpp4): implications for the origin and emergence of Middle East respiratory syndrome coronavirus. Virol J. 2013;10:304.

88. Luo CM, Wang N, Yang XL, Liu HZ, Zhang W, Li B, et al. Discovery of novel bat coronaviruses in South China that use the same receptor as Middle East respiratory syndrome coronavirus. J Virol. 2018;92(13):10.1128/JVI.00116-18.

89. Lau SKP, Fan RYY, Luk HKH, Zhu L, Fung J, Li KSM, et al. Replication of MERS and SARS coronaviruses in bat cells offers insights to their ancestral origins. Emerg Microbes Infect. 2018;7(1):209.

90. Mohd HA, Al-Tawfiq JA, Memish ZA. Middle East respiratory syndrome coronavirus (MERS-CoV) origin and animal reservoir. Virol J. 2016;13:87.

91. Moss WJ, Strebel P. Biological feasibility of measles eradication. J Infect Dis. 2011;204(Suppl 1):S47-53.

92. Chu DKW, Hui KPY, Perera R, Miguel E, Niemeyer D, Zhao J, et al. MERS coronaviruses from camels in Africa exhibit region-dependent genetic diversity. Proc Natl Acad Sci U S A. 2018;115(12):3144-9.

93. Dudas G, Rambaut A. MERS-CoV recombination: implications about the reservoir and potential for adaptation. Virus Evol. 2016;2(1):vev023.

94. Zhang Z, Shen L, Gu X. Evolutionary dynamics of MERS-CoV: potential recombination, positive selection and transmission. Sci Rep. 2016;6:25049.

95. Kim Jl, Kim YJ, Lemey P, Lee I, Park S, Bae JY, et al. The recent ancestry of Middle East respiratory syndrome coronavirus in Korea has been shaped by recombination. Sci Rep. 2016;6:18825.

96. Nelson MI, Vincent AL. Reverse zoonosis of influenza to swine: new perspectives on the human-animal interface. Trends Microbiol. 2015;23(3): 142-53.

97. Waggoner JJ, Balmaseda A, Gresh L, Sahoo MK, Montoya M, Wang C, et al. Homotypic dengue virus reinfections in Nicaraguan children. J Infect Dis. 2016;214(7):986-93.

98. Langerak T, Mumtaz N, Tolk VI, van Gorp ECM, Martina BE, Rockx B, et al. The possible role of cross-reactive dengue virus antibodies in Zika virus pathogenesis. PLoS Pathog. 2019;15(4):e1007640.

99. Shim BS, Kwon YC, Ricciardi MJ, Stone M, Otsuka Y, Berri F, et al. Zika virusimmune plasmas from symptomatic and asymptomatic individuals enhance Zika pathogenesis in adult and pregnant mice. MBio. 2019;10(4):10.1128/ mBio.00758-19.

100. Boyer S, Calvez E, Chouin-Carneiro T, Diallo D, Failloux AB. An overview of mosquito vectors of Zika virus. Microbes Infect. 2018;20(11-12):646-60.

101. Aubry M, Cao-Lormeau VM. History of arthropod-borne virus infections in French Polynesia. New Microbes New Infect. 2019;29:100513.

102. O'Donnell CD, Subbarao K. The contribution of animal models to the understanding of the host range and virulence of influenza A viruses. Microbes Infect. 2011;13(5):502-15. 
103. Bouvier NM. Animal models for influenza virus transmission studies: a historical perspective. Curr Opin Virol. 2015;13:101-8.

104. Bouvier NM, Lowen AC. Animal models for influenza virus pathogenesis and transmission. Viruses. 2010;2(8):1530-63.

105. Kwon YK, Lipatov AS, Swayne DE. Bronchointerstitial pneumonia in Guinea pigs following inoculation with $\mathrm{H} 5 \mathrm{~N} 1$ high pathogenicity avian influenza virus. Vet Pathol. 2009;46(1):138-41.

106. Van Hoeven N, Belser JA, Szretter KJ, Zeng H, Staeheli P, Swayne DE, et al. Pathogenesis of 1918 pandemic and H5N1 influenza virus infections in a Guinea pig model: antiviral potential of exogenous alpha interferon to reduce virus shedding. J Virol. 2009;83(7):2851-61.

107. Lowen AC, Mubareka S, Tumpey TM, Garcia-Sastre A, Palese P. The Guinea pig as a transmission model for human influenza viruses. Proc Natl Acad Sci U S A. 2006;103(26):9988-92.

108. Iwatsuki-Horimoto K, Nakajima N, Ichiko Y, Sakai-Tagawa Y, Noda T, Hasegawa $\mathrm{H}$, et al. Syrian hamster as an animal model for the study of human influenza virus infection. J Virol. 2018;92(4):10.1128/JVI.01693-17.

109. van der Laan JW, Herberts C, Lambkin-Williams R, Boyers A, Mann AJ, Oxford J. Animal models in influenza vaccine testing. Expert Rev Vaccines. 2008;7(6): 783-93

110. Smith WA, CH, Laidlaw PP. A virus obtained from influenza patients. Lancet, 1933;222(5732):66-8.

111. Pica N, Chou YY, Bouvier NM, Palese P. Transmission of influenza B viruses in the Guinea pig. J Virol. 2012;86(8):4279-87.

112. Lowen AC, Bouvier NM, Steel J. Transmission in the Guinea pig model. Curr Top Microbiol Immunol. 2014;385:157-83.

113. Davis AS, Taubenberger JK, Bray M. The use of nonhuman primates in research on seasonal, pandemic and avian influenza, 1893-2014. Antiviral Res. 2015;117:75-98.

114. Rimmelzwaan GF, Kuiken T, van Amerongen G, Bestebroer TM, Fouchier RA, Osterhaus AD. Pathogenesis of influenza A (H5N1) virus infection in a primate model. J Virol. 2001;75(14):6687-91.

115. Grizzard MB, London WT, Sly DL, Murphy BR, James WD, Parnell WP, et al. Experimental production of respiratory tract disease in cebus monkeys after intratracheal or intranasal infection with influenza ANictoria/3/75 or influenza A/New Jersey/76 virus. Infect Immun. 1978;21(1):201-5.

116. Matsuoka Y, Suguitan A Jr, Orandle M, Paskel M, Boonnak K, Gardner DJ, et al. African green monkeys recapitulate the clinical experience with replication of live attenuated pandemic influenza virus vaccine candidates. J Virol. 2014:88(14):8139-52.

117. Boonnak K, Paskel M, Matsuoka Y, Vogel L, Subbarao K. Evaluation of replication, immunogenicity and protective efficacy of a live attenuated cold-adapted pandemic H1N1 influenza virus vaccine in non-human primates. Vaccine. 2012;30(38):5603-10.

118. Kitano $M$, Itoh $Y$, Kodama M, Ishigaki $H$, Nakayama M, Nagata $T$, et al. Establishment of a cynomolgus macaque model of influenza $B$ virus infection. Virology. 2010;407(2):178-84.

119. Bae JY, Lee I, Kim Jl, Park S, Yoo K, Park M, et al. A single amino acid in the polymerase acidic protein determines the pathogenicity of influenza $B$ viruses. J Virol. 2018;92(13):10.1128/JVI.00259-18.

120. Park S, II Kim J, Lee I, Bae JY, Yoo K, Nam M, et al. Adaptive mutations of neuraminidase stalk truncation and deglycosylation confer enhanced pathogenicity of influenza A viruses. Sci Rep. 2017;7(1):10928.

121. Ibricevic A, Pekosz A, Walter MJ, Newby C, Battaile JT, Brown EG, et al. Influenza virus receptor specificity and cell tropism in mouse and human airway epithelial cells. J Virol. 2006;80(15):7469-80.

122. Belser JA, Gustin KM, Pearce MB, Maines TR, Zeng H, Pappas C, et al. Pathogenesis and transmission of avian influenza A (H7N9) virus in ferrets and mice. Nature. 2013:501(7468):556-9.

123. Kim Jl, Park S, Lee S, Lee I, Heo J, Hwang MW, et al. DBA/2 mouse as an animal model for anti-influenza drug efficacy evaluation. J Microbiol. 2013; 51(6):866-71.

124. Pica N, lyer A, Ramos I, Bouvier NM, Fernandez-Sesma A, Garcia-Sastre A, et al. The DBA.2 mouse is susceptible to disease following infection with a broad, but limited, range of influenza A and B viruses. J Virol. 2011;85(23): 12825-9.

125. Lutz RJ, Dedrick RL, Tuey D, Sipes IG, Anderson MW, Matthews HB. Comparison of the pharmacokinetics of several polychlorinated biphenyls in mouse, rat, dog, and monkey by means of a physiological pharmacokinetic model. Drug Metab Dispos. 1984;12(5):527-35.
126. Sutton TC, Subbarao K. Development of animal models against emerging coronaviruses: from SARS to MERS coronavirus. Virology. 2015; 479-480:247-58.

127. Belser JA, Katz JM, Tumpey TM. The ferret as a model organism to study influenza A virus infection. Dis Model Mech. 2011;4(5):575-9.

128. van Doremalen N, Miazgowicz KL, Milne-Price S, Bushmaker T, Robertson S, Scott D, et al. Host species restriction of Middle East respiratory syndrome coronavirus through its receptor, dipeptidyl peptidase 4. J Virol. 2014;88(16): 9220-32.

129. Vergara-Alert J, van den Brand JM, Widagdo W, Munoz M, Raj S, Schipper D, et al. Livestock susceptibility to infection with Middle East respiratory syndrome coronavirus. Emerg Infect Dis. 2017;23(2):232-40.

130. Widagdo W, Sooksawasdi Na Ayudhya S, Hundie GB, Haagmans BL. Host determinants of MERS-CoV transmission and pathogenesis. Viruses. 2019; 11(3):10.3390/v11030280.

131. Munster VJ, de Wit E, Feldmann H. Pneumonia from human coronavirus in a macaque model. N Engl J Med. 2013;368(16):1560-2.

132. Baseler $L$, Falzarano D, Scott DP, Rosenke R, Thomas T, Munster VJ, et al. An acute immune response to Middle East respiratory syndrome coronavirus replication contributes to viral pathogenicity. Am J Pathol. 2016;186(3):630-8.

133. Peck KM, Scobey T, Swanstrom J, Jensen KL, Burch CL, Baric RS, et al. Permissivity of dipeptidyl peptidase 4 Orthologs to Middle East respiratory syndrome coronavirus is governed by glycosylation and other complex determinants. J Virol. 2017;91(19):10.1128/JVI.00534-17.

134. de Wit E, Rasmussen AL, Falzarano D, Bushmaker T, Feldmann F, Brining DL, et al. Middle East respiratory syndrome coronavirus (MERS-CoV) causes transient lower respiratory tract infection in rhesus macaques. Proc Natl Acad Sci U S A. 2013;110(41):16598-603.

135. Coleman CM, Matthews KL, Goicochea L, Frieman MB. Wild-type and innate immune-deficient mice are not susceptible to the Middle East respiratory syndrome coronavirus. J Gen Virol. 2014;95(Pt 2):408-12.

136. Zhao J, Li K, Wohlford-Lenane C, Agnihothram SS, Fett C, Zhao J, et al, Rapid generation of a mouse model for Middle East respiratory syndrome. Proc Natl Acad Sci U S A. 2014;111(13):4970-5.

137. Agrawal AS, Garron T, Tao X, Peng BH, Wakamiya M, Chan TS, et al. Generation of a transgenic mouse model of Middle East respiratory syndrome coronavirus infection and disease. J Virol. 2015;89(7):3659-70.

138. Pascal KE, Coleman CM, Mujica AO, Kamat V, Badithe A, Fairhurst J, et al. Pre- and postexposure efficacy of fully human antibodies against spike protein in a novel humanized mouse model of MERS-CoV infection. Proc Natl Acad Sci U S A. 2015;112(28):8738-43.

139. Cockrell AS, Yount BL, Scobey T, Jensen K, Douglas M, Beall A, et al. A mouse model for MERS coronavirus-induced acute respiratory distress syndrome. Nat Microbiol. 2016;2:16226.

140. Fan C, Wu X, Liu Q, Li Q, Liu S, Lu J, et al. A human DPP4-Knockin Mouse's susceptibility to infection by authentic and Pseudotyped MERS-CoV. Viruses. 2018:10(9):10.3390/v10090448.

141. Douglas MG, Kocher JF, Scobey T, Baric RS, Cockrell AS. Adaptive evolution influences the infectious dose of MERS-CoV necessary to achieve severe respiratory disease. Virology. 2018;517:98-107.

142. Haagmans BL, van den Brand JM, Provacia LB, Raj VS, Stittelaar KJ, Getu S, et al. Asymptomatic Middle East respiratory syndrome coronavirus infection in rabbits. J Virol. 2015;89(11):6131-5.

143. Widagdo W, Okba NMA, Richard M, de Meulder D, Bestebroer TM, Lexmond $P$, et al. Lack of Middle East respiratory syndrome coronavirus transmission in rabbits. Viruses. 2019;11(4):10.3390/v11040381.

144. Houser KV, Broadbent AJ, Gretebeck L, Vogel L, Lamirande EW, Sutton T, et al. Enhanced inflammation in New Zealand white rabbits when MERSCoV reinfection occurs in the absence of neutralizing antibody. PLoS Pathog. 2017;13(8):e1006565.

145. Houser KV, Gretebeck L, Ying T, Wang Y, Vogel L, Lamirande EW, et al. Prophylaxis with a Middle East respiratory syndrome coronavirus (MERSCoV)-specific human monoclonal antibody protects rabbits from MERS-CoV infection. J Infect Dis. 2016;213(10):1557-61.

146. Prescott J, Falzarano D, de Wit E, Hardcastle K, Feldmann F, Haddock E, et al. Pathogenicity and viral shedding of MERS-CoV in immunocompromised rhesus macaques. Front Immunol. 2018;9:205.

147. Falzarano D, de Wit E, Feldmann F, Rasmussen AL, Okumura A, Peng $X$ et al. Infection with MERS-CoV causes lethal pneumonia in the common marmoset. PLoS Pathog. 2014;10(8):e1004250. 
148. Yu P, Xu Y, Deng W, Bao L, Huang L, Xu Y, et al. Comparative pathology of rhesus macaque and common marmoset animal models with Middle East respiratory syndrome coronavirus. PLoS One. 2017;12(2):e0172093.

149. Yeung ML, Yao Y, Jia L, Chan JF, Chan KH, Cheung KF, et al. MERS coronavirus induces apoptosis in kidney and lung by upregulating Smad7 and FGF2. Nat Microbiol. 2016;1:16004.

150. Adney DR, van Doremalen N, Brown VR, Bushmaker T, Scott D, de Wit E, et al. Replication and shedding of MERS-CoV in upper respiratory tract of inoculated dromedary camels. Emerg Infect Dis. 2014;20(12):1999-2005.

151. Li W, Hulswit RJG, Widjaja I, Raj VS, McBride R, Peng W, et al. Identification of sialic acid-binding function for the Middle East respiratory syndrome coronavirus spike glycoprotein. Proc Natl Acad Sci U S A. 2017;114(40): E8508-17.

152. Widagdo W, Okba NMA, Li W, de Jong A, de Swart RL, Begeman L, et al Species-specific Colocalization of Middle East respiratory syndrome coronavirus attachment and entry receptors. J Virol. 2019;93(16):10.1128/JVI. 00107-19.

153. Widagdo W, Raj VS, Schipper D, Kolijn K, van Leenders G, Bosch BJ, et al. Differential expression of the Middle East respiratory syndrome coronavirus receptor in the upper respiratory tracts of humans and dromedary camels. J Virol. 2016;90(9):4838-42..

154. Subbarao EK, London W, Murphy BR. A single amino acid in the PB2 gene of influenza A virus is a determinant of host range. J Virol. 1993;67(4):1761-4.

155. Komadina N, McVernon J, Hall R, Leder K. A historical perspective of influenza $A(H 1 N 2)$ virus. Emerg Infect Dis. 2014;20(1):6-12.

156. Bussey KA, Bousse TL, Desmet EA, Kim B, Takimoto T. PB2 residue 271 plays a key role in enhanced polymerase activity of influenza $A$ viruses in mammalian host cells. J Virol. 2010;84(9):4395-406.

157. Hatta M, Hatta Y, Kim JH, Watanabe S, Shinya K, Nguyen T, et al. Growth of H5N1 influenza A viruses in the upper respiratory tracts of mice. PLoS Pathog. 2007;3(10):1374-9.

158. Watanabe T, Kiso M, Fukuyama S, Nakajima N, Imai M, Yamada S, et al. Characterization of H7N9 influenza A viruses isolated from humans. Nature. 2013;501(7468):551-5.

159. Stray SJ, Cummings RD, Air GM. Influenza virus infection of desialylated cells. Glycobiology. 2000;10(7):649-58.

160. Jonges M, Welkers MR, Jeeninga RE, Meijer A, Schneeberger P, Fouchier RA, et al. Emergence of the virulence-associated PB2 E627K substitution in a fatal human case of highly pathogenic avian influenza virus $A(H 7 N 7)$ infection as determined by Illumina ultra-deep sequencing. J Virol. 2014; 88(3):1694-702.

161. Octaviani CP, Goto H, Kawaoka Y. Reassortment between seasonal H1N1 and pandemic (H1N1) 2009 influenza viruses is restricted by limited compatibility among polymerase subunits. J Virol. 2011;85(16):8449-52.

162. Li C, Hatta M, Nidom CA, Muramoto Y, Watanabe S, Neumann G, et al. Reassortment between avian $\mathrm{H} 5 \mathrm{~N} 1$ and human $\mathrm{H} 3 \mathrm{~N} 2$ influenza viruses creates hybrid viruses with substantial virulence. Proc Natl Acad Sci U S A. 2010;107(10):4687-92.

163. Chen LM, Davis CT, Zhou H, Cox NJ, Donis RO. Genetic compatibility and virulence of reassortants derived from contemporary avian $\mathrm{H} 5 \mathrm{~N} 1$ and human H3N2 influenza A viruses. PLoS Pathog. 2008;4(5):e1000072.

164. Song MS, Pascua PN, Lee JH, Baek YH, Park KJ, Kwon HI, et al. Virulence and genetic compatibility of polymerase reassortant viruses derived from the pandemic (H1N1) 2009 influenza virus and circulating influenza A viruses. J Virol. 2011;85(13):6275-86.

165. Fodor E, Devenish L, Engelhardt OG, Palese P, Brownlee GG, Garcia-Sastre A. Rescue of influenza A virus from recombinant DNA. J Virol. 1999;73(11): 9679-82.

166. Hoffmann E, Neumann G, Kawaoka Y, Hobom G, Webster RG. A DNA transfection system for generation of influenza A virus from eight plasmids. Proc Natl Acad Sci U S A. 2000;97(11):6108-13.

167. Govorkova EA, Murti G, Meignier B, de Taisne C, Webster RG. African green monkey kidney (Vero) cells provide an alternative host cell system for influenza A and B viruses. J Virol. 1996;70(8):5519-24.

168. Seitz C, Frensing T, Hoper D, Kochs G, Reichl U. High yields of influenza A virus in Madin-Darby canine kidney cells are promoted by an insufficient interferon-induced antiviral state. J Gen Virol. 2010;91(Pt 7):1754-63.

169. Kumari K, Gulati S, Smith DF, Gulati U, Cummings RD, Air GM. Receptor binding specificity of recent human H3N2 influenza viruses. Virol J. 2007;4:42.

170. Li IW, Chan KH, To KW, Wong SS, Ho PL, Lau SK, et al. Differential susceptibility of different cell lines to swine-origin influenza A H1N1, seasonal human influenza A H1N1, and avian influenza A H5N1 viruses. J Clin Virol. 2009;46(4):325-30.

171. Kuiken T, Riteau B, Fouchier RA, Rimmelzwaan GF. Pathogenesis of influenza virus infections: the good, the bad and the ugly. Curr Opin Virol. 2012;2(3): 276-86.

172. Gralinski LE, Baric RS. Molecular pathology of emerging coronavirus infections. J Pathol. 2015;235(2):185-95.

173. Herfst S, Chutinimitkul S, Ye J, de Wit E, Munster VJ, Schrauwen EJ, et al. Introduction of virulence markers in PB2 of pandemic swine-origin influenza virus does not result in enhanced virulence or transmission. J Virol. 2010; 84(8):3752-8.

174. Maines TR, Jayaraman A, Belser JA, Wadford DA, Pappas C, Zeng H, et al. Transmission and pathogenesis of swine-origin 2009 A(H1N1) influenza viruses in ferrets and mice. Science. 2009;325(5939):484-7.

175. Garten RJ, Davis CT, Russell CA, Shu B, Lindstrom S, Balish A, et al. Antigenic and genetic characteristics of swine-origin 2009 A(H1N1) influenza viruses circulating in humans. Science. 2009:325(5937):197-201.

176. Itoh Y, Shinya K, Kiso M, Watanabe T, Sakoda Y, Hatta M, et al. In vitro and in vivo characterization of new swine-origin $\mathrm{H} 1 \mathrm{~N} 1$ influenza viruses. Nature. 2009;460(7258):1021-5.

177. El-Shesheny R, Feeroz MM, Krauss S, Vogel P, McKenzie P, Webby RJ, et al. Replication and pathogenic potential of influenza A virus subtypes $\mathrm{H3}, \mathrm{H} 7$, and $\mathrm{H} 15$ from free-range ducks in Bangladesh in mammals. Emerg Microbes Infect. 2018;7(1):70

178. Uraki R, Kiso M, Shinya K, Goto H, Takano R, Iwatsuki-Horimoto K, et al. Virulence determinants of pandemic A(H1N1)2009 influenza virus in a mouse model. J Virol. 2013;87(4):2226-33.

179. Pekosz A, Newby C, Bose PS, Lutz A. Sialic acid recognition is a key determinant of influenza A virus tropism in murine trachea epithelial cell cultures. Virology. 2009;386(1):61-7.

180. Glaser L, Conenello G, Paulson J, Palese P. Effective replication of human influenza viruses in mice lacking a major alpha2,6 sialyltransferase. Virus Res. 2007;126(1-2):9-18.

181. Ng WC, Londrigan SL, Nasr N, Cunningham AL, Turville S, Brooks AG, et al. The C-type lectin Langerin functions as a receptor for attachment and infectious entry of influenza A virus. J Virol. 2016;90(1):206-21.

182. Londrigan SL, Turville SG, Tate MD, Deng YM, Brooks AG, Reading PC. Nlinked glycosylation facilitates sialic acid-independent attachment and entry of influenza A viruses into cells expressing DC-SIGN or L-SIGN. J Virol. 2011; 85(6):2990-3000.

183. Nicholls JM, Chan RW, Russell RJ, Air GM, Peiris JS. Evolving complexities of influenza virus and its receptors. Trends Microbiol. 2008;16(4):149-57.

184. Hughes MT, McGregor M, Suzuki T, Suzuki Y, Kawaoka Y. Adaptation of influenza A viruses to cells expressing low levels of sialic acid leads to loss of neuraminidase activity. J Virol. 2001;75(8):3766-70.

185. Ilyushina NA, Khalenkov AM, Seiler JP, Forrest HL, Bovin NV, Marjuki H, et al. Adaptation of pandemic H1N1 influenza viruses in mice. J Virol. 2010;84(17): 8607-16.

186. Stevens J, Blixt O, Tumpey TM, Taubenberger JK, Paulson JC, Wilson IA Structure and receptor specificity of the hemagglutinin from an $\mathrm{H} 5 \mathrm{~N} 1$ influenza virus. Science. 2006:312(5772):404-10.

187. de Vries RP, Peng W, Grant OC, Thompson AJ, Zhu X, Bouwman KM, et al. Three mutations switch H7N9 influenza to human-type receptor specificity. PLoS Pathog. 2017;13(6):e1006390.

188. Liu Q, Zhou B, Ma W, Bawa B, Ma J, Wang W, et al. Analysis of recombinant H7N9 wild-type and mutant viruses in pigs shows that the Q226L mutation in HA is important for transmission. J Virol. 2014;88(14):8153-65.

189. Xu Q, Wang W, Cheng X, Zengel J, Jin H. Influenza H1N1 A/Solomon Island/ $3 / 06$ virus receptor binding specificity correlates with virus pathogenicity, antigenicity, and immunogenicity in ferrets. J Virol. 2010;84(10):4936-45.

190. Imai M, Watanabe T, Hatta M, Das SC, Ozawa M, Shinya K, et al. Experimental adaptation of an influenza $\mathrm{H} 5 \mathrm{HA}$ confers respiratory droplet transmission to a reassortant $\mathrm{H} 5 \mathrm{HA} / \mathrm{H} 1 \mathrm{~N} 1$ virus in ferrets. Nature. 2012; 486(7403):420-8.

191. Xu R, Zhu X, McBride R, Nycholat CM, Yu W, Paulson JC, et al. Functional balance of the hemagglutinin and neuraminidase activities accompanies the emergence of the $2009 \mathrm{H} 1 \mathrm{~N} 1$ influenza pandemic. J Virol. 2012;86(17): 9221-32.

192. Park S, Lee I, Kim Jl, Bae JY, Yoo K, Kim J, et al. Effects of HA and NA glycosylation pattern changes on the transmission of avian influenza $A(\mathrm{H} 7 \mathrm{~N} 9)$ virus in Guinea pigs. Biochem Biophys Res Commun. 2016;479(2):192-7. 
193. Raj VS, Mou H, Smits SL, Dekkers DH, Muller MA, Dijkman R, et al. Dipeptidyl peptidase 4 is a functional receptor for the emerging human coronavirusEMC. Nature. 2013;495(7440):251-4.

194. Garcia-Sastre A, Egorov A, Matassov D, Brandt S, Levy DE, Durbin JE, et al. Influenza A virus lacking the NS1 gene replicates in interferon-deficient systems. Virology. 1998;252(2):324-30.

195. Smith JH, Brooks P, Johnson S, Tompkins SM, Custer KM, Haas DL, et al. Aerosol vaccination induces robust protective immunity to homologous and heterologous influenza infection in mice. Vaccine. 2011;29(14):2568-75.

\section{Publisher's Note}

Springer Nature remains neutral with regard to jurisdictional claims in published maps and institutional affiliations.

Ready to submit your research? Choose BMC and benefit from:

- fast, convenient online submission

- thorough peer review by experienced researchers in your field

- rapid publication on acceptance

- support for research data, including large and complex data types

- gold Open Access which fosters wider collaboration and increased citations

- maximum visibility for your research: over $100 \mathrm{M}$ website views per year

At $B M C$, research is always in progress.

Learn more biomedcentral.com/submissions 